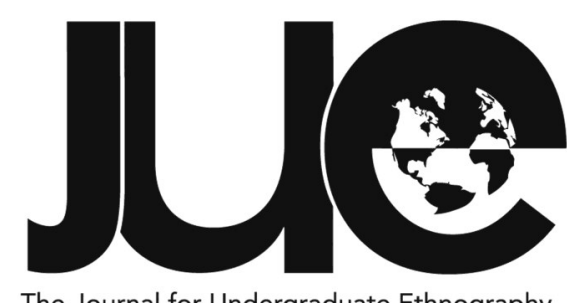

The Journal for Undergraduate Ethnography

\title{
"A good conversation is better than a good bed": How Migration Impacts Meanings of Health among Chronically III Ethiopian Immigrant Women
}

\section{Meklit Daniel}

University of Cambridge, meklitd147@gmail.com

\section{ABSTRACT}

Narratives reinstate meaning to the body and mind, especially after major life events like migration and illness. To better understand the interplay between migration status and narrative practices, I examine the functions and meanings of illness narratives among three Ethiopian immigrant women living with chronic illnesses. I investigate how these accounts impact the ways in which my interviewees identify and understand themselves in relation to their illnesses. The core of this article is divided into three sections-Stigma, Frustration, and Faith-each conveying my interlocutors' migration and chronic illness experiences as well as the liberating and constraining effects of storytelling. Collectively, these themes highlight the agentive aspects of illness narratives that help chronically ill Ethiopian immigrant women assert control over their bodies and identities as they strive toward bettering their health.

Keywords: chronic illness; illness narratives; migrant health; women's health; Ethiopia 


\section{Introduction: To Take Control by Sharing the Truth}

On a chilly Sunday evening in January of 2020, Almaz and I attended the local Wollo Association's Christmas celebration. The Wollo Association is a social club established to connect and support Ethiopian immigrants living in the Washington, D.C. metropolitan area with origins in the northeastern Wollo province. As Almaz and I entered the packed venue, we were greeted by familiar sights, sounds, and scents. Near the entrance to the left was a group of giggling children playing with each other. Three women were busily reheating wot (stew), replenishing a platter of injera (sour fermented flatbread), and brewing shai (tea) and bunna (coffee) in the kitchen in front of us. And in between these two spaces was the living room, filled with the rest of the association members. They were dressed in their best traditional attire and sat in a circle, surrounding a pile of shiny presents for the White Elephant game. Almaz quickly joined a friend while I, alone and without a seat, squeezed myself next to two other people on a two-person couch.

The association meeting officially commenced once bunna and shai were served. The club's president stood up at the edge of the living room and made several announcements in Amharic, the lingua franca of Ethiopia. He reminded the members to review their contact information on the attendance sheet being passed around the room and to pay their membership dues before leaving the meeting. Then, he asked for everyone's attention: "We have a returning member with us today, and she would like to say a few words for us." A middle-aged woman seated not far away from me arose shyly, holding her right hand. In
Amharic, she introduced herself in a gentle yet nervous voice:

$\mathrm{Hi}$ everyone, my name is Rahel. I used to participate in the Wollo meetings, but I stopped coming to the last few meetings because of my right hand. I don't know why, but about four months ago, my right hand began to hurt every night around 12 a.m. I had trouble sleeping, but I feel better now. I know I missed a lot of meetings, but I want to rejoin this association. I promise to pay my past dues. I hope you all will allow me to join again.

Rahel sat down. The room was silent. Everyone had sympathetic looks on their faces. "Thank you for speaking, Rahel," interrupted the association president. "Don't worry about anything. The board will discuss how we can help you pay the past dues. Just enjoy tonight's festivities." A few minutes later, the party's mood lightened with the start of White Elephant. While the guests playfully bickered over the presents, I noticed Rahel in deep conversation with the people around her. It seemed that her problems were solved, and she was welcomed back into the association. Yet, I noticed her spacing out as the members danced to traditional Wollo music for the rest of the night. It appeared as if Rahel was processing what she had just done-narrate her pain and suffering.

Rahel's disengagement from the Wollo Association draws attention to how cultural beliefs affect sick individuals' responses toward their health conditions. Within Ethiopian culture, a notion of pride-that is, a set of culturally specific ideas that emphasizes independence and self-sufficiency-is vital. This belief becomes particularly important for Ethiopian immigrants, who are adjusting to unfamiliar environments in their countries of resettlement and who must assert their success in a new land for their family members, compatriots, and fellow immigrants. Personal struggles like illness become stigmatized issues that are not openly discussed among Ethiopian community members. Instead, these individuals enact a performance, appearing to be healthy when, in reality, this cultural expectation prevents Ethiopians in need from getting help. Ethiopian social clubs are established to help 
immigrants hold onto remnants of home while providing financial, emotional, and spiritual support for those in strenuous circumstances. But for Rahel, the Wollo Association did not fulfill this purpose. She withdrew from the organization due to the cultural shame and fear engendered by her chronic pain. When Rahel explained her absence to the association, her bodily movements, like lowering her head and clutching her ached hand, conveyed Rahel's humiliation in revealing her weakness. At a glance, this behavior appears defeatist, but I contend that Rahel was carrying out an empowering act. She was finding the words to capture her illness experience. Constructing this narrative was an important step that helped Rahel heal. She was rebuilding her relationship with the association members, gaining control over her life narrative and telling her truth (Frank 1995, xii).

This article draws upon my undergraduate senior honors thesis in which I ethnographically examined the chronic illness experiences of Ethiopian immigrant women living in the Washington, D.C. metropolitan area. My fieldwork lasted from January 2019 to January 2020. I collected the life histories of five chronically ill Ethiopian immigrant women, conducted twelve semi-structured interviews with local Ethiopian women and men, and interned at a local immigrant health clinic. An emphasis on life history helped me develop rapport with my interlocutors through multiple visits. This approach provided these womenmy "primary interlocutors"-greater control over the interview process. I have relatives who reside in the D.C. metropolitan area and so I gathered many of my informants with their help through snowball sampling. Snowball sampling is a nonrandom method that could lead to nonresponse bias or a selection of respondents who constitute a distinct social network. But as an outsider to the D.C. Ethiopian diaspora community, this approach was crucial for me to get "inside" my study population (Beaman 2017). Rather than being "controlled away," my participants' distinct characteristics are "understood, developed, and incorporated" throughout my analysis (Beaman 2017, 126).
I also identified interviewees by attending local Ethiopian community events. Most of my interviews were conducted in English and Amharic at my interlocutors' places of residence. If more convenient, some of these conversations were held over the phone. In this article, I have transcribed my interlocutors' responses as spoken rather than "correcting" them to standard English. Additionally, I conducted semi-structured interviews with local Ethiopian residents to understand how blood, fictive, and ethnic kinships affect chronic illness care. These informants included Ethiopian women and men, who ranged in profession, age, and years of residence in the U.S. I have changed all of my interlocutors' names in my study to protect their privacy. Lastly, I interned at a local immigrant medical clinic, where I shadowed different health personnel and conducted a needs assessment on the center's health promotions program. Through this clinical perspective, I was able to better comprehend and build upon my interlocutors' illness accounts.

In this article, I examine the functions and meanings of illness narratives among three of my primary interlocutors to better understand the interplay between migration and narrative practices. I investigate how these accounts impact the ways in which my interviewees identify and understand themselves in relation to their illnesses. However, I do not simply describe my participants' narratives. Rather, I add the impact of social networks to these stories because illness narratives change when shared with different audiences. Indeed, the accounts included in this article are interpreted through my perspective as a second-generation Ethiopian American woman, yet my goal is to demonstrate the liberating and constraining aspects of storytelling among my interlocutors.

The core of this paper is divided into three sections-Stigma, Frustration, and Faith. Each section begins with a vignette about one of my interlocutors and subsequently analyzes this account. In Stigma, I examine Genet's nearly fatal struggle with disclosing her diabetes status to her family. Understanding the stigma around her disclosure contextualizes the social worlds Genet must navigate to make sense of her illness. Frustration explores Haset's resentment 
toward her diagnosis of hypothyroidism. Although Haset felt physically well, empirical data disregarded her perspective, drawing attention to the contentious division between "objective" and "subjective" health measurements. The focus of Faith is Almaz's mixed response to her diabetes diagnosis. Although she mostly adheres to her treatment, Almaz relies on her Ethiopian Orthodox Christian faith to explicate her illness and to maintain hope about her future well-being, thus pointing to the fraught relationship between biomedical and cultural views of health. Altogether, these themes highlight the agentive aspects of illness narratives that help chronically ill Ethiopian immigrant women assert control over their bodies and identities as they strive towards bettering their health.

\section{Habesha People in the U.S.: How Migration Affects Social Networks}

With an estimated 256,032 residents, first-generation Ethiopian immigrants are the second largest African immigrant group in the U.S. after Nigerians (US Census 2019a; Migration Policy Institute 2014). Nearly 60\% of first-generation Ethiopian immigrants arrived in the U.S. after 2000, but their first significant wave of resettlement occurred during the 1980s and 1990s (Migration Policy Institute 2014). These decades were turbulent times in Ethiopian history as the country withstood an oppressive political regime, a civil war, and severe food shortages. Consequently, many Ethiopians sought refuge in nearby Sudan, Djibouti, Somalia, and Kenya while others relocated to Europe, North America, and Australia. In the U.S., about 1,000 Ethiopians were resettled annually between 1981 and 1993 (Capps, McCabe, and Fix 2014).

Of importance at this time, tens of thousands of Eritreans left their homeland due to the Eritrean War of Independence (ca. 19611991). Prior to Eritrea's secession from Ethiopia, the exact number of Eritreans in the U.S. was unknown as they were counted as Ethiopian nationals. But as of 2019, there are about 49,355 Eritreans living in the U.S. (US Census 2019a). Despite Eritrea's separation, Eritreans and Ethiopians are often referred to collectively as Habesha, a word that has been generally embraced within the Eritrean and Ethiopian diaspora. These deeply rooted cultural connections have influenced where Habesha immigrants live in the U.S.

The Habesha diaspora is distributed widely across the U.S. Most first-generation Eritrean immigrants reside in southern California with an estimated population of 9,156 in the entire state (US Census 2019b). The greater Washington, D.C. area has the largest Ethiopian immigrant population in the U.S. with about 35,000 first-generation Ethiopian immigrants (Migration Policy Institute 2014). D.C. is a cosmopolitan city, yet it is considered more manageable in size, living costs, and traffic than other major U.S. cities, like New York, Los Angeles, and Chicago. As Jill Wilson and Shelly Habecker (2008) write in "The Lure of the Capital City," the development of immigrant enclaves attracts new migrants to established educational, religious, and cultural institutions (cf. Massey 1990). The social networks within these communities become fortified and enlarged "through transnational activities organized around a variety of ethnic, national, political, and religious affiliations and identifications" (Wilson and Habecker 2008, 444). Altogether, these connections critically shape immigrants' health.

Studies have demonstrated that people with high levels of social support have lower risks of mortality than those who have weaker support networks (Wright 2016; cf. Berkman and Syme 1979; Cohen, Gottlieb, and Underwood 2000). Further, positive social support can reinforce healthy behaviors while negative social aid can deter healthy behavioral changes (Wright 2016; cf. Revenson et al. 1991; Goldsmith 2004). Accordingly, individuals' health outcomes depend not simply on their physiology and actions but also on their physical environment and the behaviors of people around them (Smith and Christakis 2008). Some studies indicate the entangled sociocultural, psychological, and environmental factors that shape people's social networks and subsequently health (Wright 2016). These phenomena are most drastic for immigrants whose social networks are also fractured by relocation. 
Migration affects the robustness of immigrants' social networks. This process puts immigrants' kinship relations to the test as some immigrants cannot visit or bring their family and friends to their destination countries (Brettell 2008). These issues are further complicated with the addition of chronic medical issues. Chronic illnesses not only encompass the daily experiences of pain and suffering; they integrate into sick people's lives, becoming inseparable from their life histories and worlds. Adjusting to and making sense of such profound changes are difficult, but illness narratives help reinstate order to everyday life.

\section{Illness Narratives: Restoring Order to the Self}

Illness narratives are powerful and necessary forms of self-understanding. Medical sociologist Michael Bury $(2001,264)$ contends that at its fundamental level, storytelling "help[s] sustain and create the fabric of everyday life...[and] repair and restor[e]...meaning." Narratives reinstate meaning to the body, mind, and life, which have all been threatened by illness (Bury 2001, 264). Bury's explication of narratives echoes psychiatrist and medical anthropologist Arthur Kleinman's definition of illness as "conjuring the innately human experience of symptoms and suffering" (1988, 3). Illness also impacts sick individuals and their social networks (Kleinman 1988). In turn, illness narratives have various functions, like making sense of illnesses' origins or conveying cultural notions of pain and suffering (Bury 2001, 263). We must go beyond Bury and Kleinman's structural functionalist views of illness, however, to understand the fluid relationship between illness and narratives.

People have stories about past, present, and future life experiences that are influenced by the body's ability to fulfill certain goals and plans. But as medical sociologist Arthur Frank $(1995,1)$ writes, new stories are needed when critical illnesses disrupt a sick person's "destination and map" of life. Frank $(1995,55)$ contends that "self-stories"-in which "the self is being formed in what is [being] told"-help sick people emerge from the "narrative wreckage" with a new sense of direction. Self-stories, and illness narratives more generally, usher "'greater continuity and closure"' for their narrators, influencing how people live and understand their truths (Zipes 2012, 127). My research contributes to Frank's notion of illness narratives by conveying what self means and how it is constructed by my interlocutors as immigrant women living with chronic health conditions. It is through this approach that we can understand how personal truths about health arise from within and through social relations.

Each person has chosen and unchosen stories. In Letting Stories Breathe, Frank (2010, 25) develops this idea by building upon Pierre Bourdieu's concept of "chosen" and "unchosen choices." Individuals hold socially rooted dispositions that stem from their families' beliefs and behaviors. Since people are not born into families of their choice, unchosen stories inevitably arise within these social environments and shape individuals' identities. Simultaneously, people can decide whether to retell certain stories and how to do so. In the midst of these competing narratives, people grow through personally selected accounts derived from "collection[s] of stories in which a life is formed" (Bourdieu 1984, 49; see also Zipes 2012, 128). For chronically ill immigrants, illness is just one type of significant interruption in their personal narratives. Developing new self-stories can be challenging for immigrants as they navigate through the unfamiliar terms and tropes of their destination countries. Immigrants present chosen stories about their illness experiences, having assessed unchosen narratives that were created in the social environments of their upbringing. Moreover, they weave together multiple frameworks to create their self-stories. Some of these structures relate closely to native cultural beliefs while others align with values upheld in their countries of relocation. In essence, immigrants construct their stories based on continually changing frames of reference. Recognizing the selectivity and fluidity of storytelling underlines that immigrants inhabit multiple worlds and that they are active agents in crafting their life stories.

In all, these perspectives on illness narratives point to the variability of stories. Such differences depend on the narrator's audience 
and contexts, indicating the intersubjective nature of illness. As Smith and Christakis (2008, 406) contend, "[p]eople are interconnected, and so their health is interconnected" through biological, social, and environmental factors. These elements have greater significance for immigrants. When migrants enter a new country, their social connections dramatically change as they confront adjustment to a new land. Simultaneously, immigrants learn to share their experiences in new ways and to attain control over meaningful interpretations of their lives.

\section{Stigma: When Disclosing a Health Condition is a Decision between Life or Death}

“For Ethiopians, when you have pain, you don't go to the doctor until the pain doesn't let you get out of bed!" asserted Genet. She and I were seated next to each other at her dining table. It was my first time meeting Genet, but she openly shared her life experiences in a mix of Amharic and English. For Genet, the combination of uncertainty, stress, and fear contributed to her development of type 2 diabetes. As she indicated in her opening remarks, the anticipated cultural response to pain and suffering among Ethiopians is to ignore these symptoms until they interfere with everyday life functions. Such expectations echo the cultural notion of pride mentioned earlier and how this trait is a performance of strength during personal battles (Hatch 1989).

Genet was born in 1966 in Menjar, a town two hours east of Addis Ababa. She grew up in both cities with her mother, two older brothers, and younger sister. Genet had a "good" life in Ethiopia. But due to Ethiopia's political instability after the 1991 dissolution of the Marxist Derg, Genet left Ethiopia for Cairo, Egypt, in 1998, where she worked as a nanny for a wealthy Egyptian family. When recalling her time in Egypt, Genet often stared into the distance with a smile on her face: "I was sitter for a boy of a rich family. I took care of him from when he was nine months to seven years. I enjoyed taking care of him. Those experience help me understand what means to be mother. I learned what means to raise, love, and take good care of kids."
After living in Egypt for seven years, Genet decided to immigrate to the U.S. She "didn't expect to come to America" because she did not have any relatives living there, but Genet decided to give it a chance. She arrived in Washington, D.C., where there was a community of Ethiopian migrants who had worked in Egypt. Genet applied for asylum, but her application was rejected-the first of many dismissals. Genet described her determination to submit a successful application with her lawyer's support: "My lawyer encouraged me to apply again and again. He hustle me to reapply for asylum.... Time to time, one year, two years, three, four. It became very exhausting." About four years into this process, Genet received her work permit, and she began working various service jobs. Six years later in 2015, Genet finally received her permanent residency card. Upon reflection, Genet does not take her immigration status for granted: "This all things in the past, but I'm emotionally hurt. It's difficult being immigrant whatever it is. Paper doesn't mean nothing.... I always told myself, 'I have to do something. I must always try to do something.... I must be patient."' Genet's determination paid off, but the emotional scars from this journey affected her physical health.

Genet began experiencing type 2 diabetes symptoms in 2008. At first, she tried to downplay these signs: "When I was developing diabetics, I know some of the symptoms-dry mouth, thirsty. I drank a lot of water. I'm never satisfied with how much water I drank! I ate a lot of sweets and carbs...[but] I denied having diabetics." When Genet's friends saw these behavioral changes, they advised her to visit a physician before her health worsened. Eventually, Genet complied and learned of her health status. She was distraught. "I never had this issue before," recounted Genet with slight desperation in her voice. "I was panicking-my paper, my health. I was upset." This physiological development was a sign of failure for Genet. Her illness implied that she was not strong enough to withstand the biological and legal problems in her life. At this moment, migration challenges Genet's ability to deal with her health conditions. Immigrants have higher expectations of their adjustment in their destination countries due to the greater risks of leaving their home countries and supporting 
loved ones. Consequently, immigrants like Genet pay a greater price for displaying a front of self-sufficiency to deter serious problems.

Since her diagnosis, Genet has learned that she has power over her health. She asserted, "I can have command over diabetics by watching what I eat, exercising, [and] eating correct, small portions." Genet has to face the everyday realities of living with type 2 diabetes, like checking her blood glucose levels and giving proper insulin injections before each meal. These routines are daily reminders of her chronic illness, and they possess a degree of shame that Genet must overcome internally. When Genet became a permanent resident, she had an easier time coming to terms with her health condition because this legal resolution affirmed her life's "destination and map" (Frank $1995,1)$. What Genet had yet to confront, however, was dealing with stigma from her family.

When Genet traveled to Ethiopia to visit her family in 2015, she did not tell them about her health issue until it became a life or death decision. "I didn't want to tell my family that I have diabetics, but I had to," shares Genet. That critical moment arrived when Genet and her mother attended an Ethiopian Orthodox Church service in Menjar. Typically, these ceremonies begin before dawn and end midday (Sellasie and Mikael 1970). Attendees go to church without having eaten food, and they break their fast with dabo (bread). This ritual became a problem for Genet when she became hungry to the point of almost passing out. Genet described the moment at which she told her mother that she felt faint: "I [told] my mom I was not feeling good because of diabetics. She said, 'Oh, my child! How I can bring you here and hurt you without giving you food?! Let me find you food.' She went to other people and got bits of bread. I ate it and felt better." At that moment, Genet was faced with the decision to disclose her health status. She had to resist the cultural notion of pride within a sacred place, where people exposed their vulnerabilities to God. Genet had not imagined sharing her illness then but doing so saved her life. In fact, this action led her to gain moral support from her family and to educate them about nutritional health.
A central theme in Genet's account is loss of control in both tangible and intangible ways. Before her diagnosis, Genet had trouble getting her residency card. She was obliged to work hard and create a self-sufficient U.S. American life, which financially supported her family in Ethiopia, but Genet did not have command over her legal status in the U.S. In such circumstances, migration contributes to Genet's loss of control over her life. Genet relocates to two different countries, where she must adjust to unfamiliar cultural norms. Genet's ability to create a stable life, specifically in the U.S., depends on her constant flexibility and willpower to attain her permanent residency status. Ultimately, Genet's determination pays off, but she had to endure a decade of not knowing whether she would stay in the U.S. On an interpersonal level, migration impedes Genet's family role. Many immigrants leave their native countries to provide better economic support for their relatives. But for Genet, migration to the U.S. disrupts her ability to fulfill this role. As a daughter, Genet bears a cultural responsibility to assist her family in Ethiopia (Bekele 2018). Genet carries out this duty by sending remittances, but due to her prolonged legal issues, these pressures exacerbate her health and well-being.

Genet's diagnosis also precipitates loss of control over her body. The concept of control is important when examining Genet's experiences because it frames how individuals perceive their lived realities. Control implies a degree of predictability in life; it "does not require selfconscious monitoring" as Frank contends (1995, 30). However, illness engenders unpredictability, restricting everyday freedoms. For Genet, diabetes is another reminder of her body's limitations as an immigrant and a chronically ill woman. But rather than simply bearing uncertainties, illness also compels adjustment to uncontrollability.

Illness signifies adaptation to the crisis of contingency. Frank (1995, 31) defines contingency as the "body's condition of being subject to forces that cannot be controlled." At infancy, people cannot control their bodies, thus burping or spitting at their own pace. But in adulthood, individuals are expected to control their bodily functions. Loss of that 
command is perceived as a social failure, and adults are expected to regain this control or to hide that loss effectively (Frank 1995). The latter pressure is more significant for Genet because of the cultural notions of self-pride.

Further, Genet's circumstances underline the tension between notions of individual and social honor. Individual honor assumes that the "agent's focus is primarily inward upon his or her own sense of self-worth. The underlying motivation is to achieve a sense of personal accomplishment or fulfillment, and the individual does so by engaging in activities or exhibiting qualities that are defined by the society as meritorious" (Hatch 1989, 349). Genet demonstrates individual honor by sending remittances to her family. Migration bears personal and interpersonal responsibilities, and Genet's desire for self-sufficiency honors herself and her sacrifices. She creates a meaningful understanding of her life through these deeds.

Such an intrinsic drive clashes with social expectations of honor. Social honor in Ethiopian culture is significantly influenced by the Ethiopian Orthodox Church. Diego Malara and Tom Boylston $(2016,53)$ argue that life is considered from an asymmetrical relational perspective; that is, "[r]elationships-with family members, institutions, Church, and God-are shaped both by the circumstances of power and by notions of the good (the mercy and protection of God, the love of Mary, the authority of fathers)." Social honor emphasizes selflessness and a type of love that is "unequal and non-reciprocal" (Malara and Boylston 2016, 53). In Genet's life, social honor takes the form of repatriating money despite her legal and health issues. Her resettlement in the U.S. is an extension of her family's journey, and she is expected to provide for her loved ones as a woman. These cultural notions of honor dictate Genet's body to an extent, controlling how she navigates life in the U.S. as a chronically ill immigrant woman. Such assumptions are part of Genet's unchosen stories that are rooted in Ethiopian customs and the challenges engendered by migration.

Illness disrupts people's lives, but illness narratives help address this interruption. According to Frank $(1995,59)$, illness narratives have two functions-to restore a fragmented order and to tell the truth about this life change. Genet's story attempts to organize the jarring pieces of her life. In this process, we see her narrative making strides at the eternal return. Philosopher Genevieve Lloyd (1993: 120) interprets this concept conceived by Friedrich Nietzsche as "a matter rather of seeing everything that happens-whether it be grand or unbearably petty-as integral to the being of a self which...could do so only in its entirety." Genet shares the internal and interpersonal struggles of dealing with her health and legal challenges in her story. She addresses stigmatized cultural issues directly, yet to an extent, her openness is confounded by her retrospective position. It has been about twelve years since Genet was diagnosed with type 2 diabetes. She has adjusted to her daily health regimens, and she has accepted her diagnosis. Accordingly, Genet's story conveys a heroic tone, which conveys her triumph over incredible obstacles. Being removed from the past has allowed Genet to better understand her experiences and to craft her own narrative. Her body is no longer "imprisoned" by the emotional challenges brought by diabetes and her immigration status (Frank 1995, 98). Genet is not controlled by the chaos in her life. She has found internal peace.

\section{Frustration: A Clash of Biomedical and Personal Narratives}

Haset learned that she had an abnormal thyroid stimulating hormone (TSH) count during her annual physical examination in 2015. "[My doctor] told I have a problem with my thyroid," recounted Haset hesitantly over the phone. "He say, 'This okay. That okay.' And then, 'The thyroid number is high."' Haset was confused. She had consistently visited her primary care doctor each year, and there was often nothing of significant concern with her health. But now, a numerical discrepancy pointed to a problem. "When I heard the news, I was not- I was not really happy," sighed Haset in frustration. "I thought, the way I feel-I thought $100 \%$ healthy. When he tell me [that I have a high TSH count], that make confused. Unhappy." Despite Haset not feeling physically unwell, her physician referred her to an endocrinologist, who conducted more tests. Interestingly, the endocrinologist was also puzzled at Haset's 
diagnosed thyroid issues inquiring, "'Oh, [are] you really sick? I don't feel anything. I don't see anything. There is no swollen."' But because Haset's TSH count indicated an abnormality, her endocrinologist and primary care physician officially diagnosed her with hypothyroidism, which Haset does not fully accept to this day.

Haset was born on December 13, 1966, outside of Addis Ababa, Ethiopia. As the ninth child of twelve siblings, Haset was raised by her oldest brother, Getachew, who was roughly thirty years older than her. Despite being soft-spoken, Haset laughed heartily at different childhood memories, especially with her neighborhood friends: "There is always to see something. 'Oh, so and so dress up. Oh, she's going now. Look, her shoes!'... We always sneaking from the house, going backyard, playing." Haset's fond memories, however, were pockets of glee overshadowed by the Derg. Believing she would have a safer life, Getachew sent Haset to Takoma Park, Maryland, in 1988 to live with their brother. Haset worked various service jobs as a senior living facility food server, an airport gift shop cashier, and a gas station clerk. After fifteen years of living in the U.S., during which Haset got married and had three children, she enrolled in a certified nurse assistant (CNA) course. She then began working at a local hospital, which Haset emphasized as "stressful" but also compelling to live healthily.

When Haset returned to her primary care doctor after her hypothyroidism diagnosis, she received a complicated medical regimen: "I start with 25 milligram for three months. He say, 'Oh, that's not enough.' He increase it, fifty milli, and then he see it. I don't know what happen. He increase it again, seventy-five [micrograms]. I took seventy-five [micrograms] for two, three years." Haset did not notice major changes with her TSH count as she took the medication, but she felt its side effects. In an irritated voice, Haset recalled, "[T] he side effects is hurt me bad, like losing hair, drying my hair. My throat dry. It just-Skin issue it even cost too." Haset changed her primary care doctor to another one, who reduced her medication to seventyfive micrograms for three days a week. Yet, Haset still did not feel sick because of the illness, making her believe she was misdiagnosed: "Yeah, my inside say, 'I thought it's wrong diagnose because I don't have feeling.' Still I don't! There is no sickness or anything. It just playing with the number. I just feeling-my feeling, my body. Are they [the physicians] really right? Is there something wrong?" For Haset, the numbers have no meaning without physical symptoms.

Additionally, Haset is frustrated by her diagnosis because she was not properly educated about her health condition. At first, Haset construed her illness as hyperthyroidism based on her childhood observations of this condition. She remembered, "Back home [in Ethiopia], when somebody has thyroid [issues], it's not really thyroid the way they put here [in the U.S.]. It's swollen! Somebody neck is swollen. A big gland is coming out." The physical presence of this illness frightened Haset. People would know that she is sick and stigmatize her appearance. Haset's worries subsided when her coworkers, who also have hypothyroidism, reassured her with their experiences of living with this illness.

Further, Haset did not realize that hypothyroidism was a chronic condition upon her diagnosis. She asked her doctor, "Is it temporary I'm taking this medicine [sic]?" But he replied, "No, it's forever!" The idea of forever shocked Haset, which she described as "hit[ting] me in the head." Haset had assumed that her diagnosis was simply a minor event in her life; she would overcome this challenge and carry on. However, Haset had to grapple with the fact that chronic illness is a long-term adjustment to everyday disruptions in life. Initially, Haset perceived her illness "like a headache. I will get over with this thing." But throughout her experience with hypothyroidism, Haset realized that her illness "means...a big deal. Thyroid is not [an] easy disease. It's really bad. It control your-all your body." Yet, she did not anticipate the side effects of her medication. Hair loss, dry hair, and weight gain all affected key feminine aspects of Haset's physical appearance, but these changes were deemed trivial by her physician. Altogether, her doctor's lack of empathy, combined with the influence of biomedical narratives, reinforced Haset's frustration about her diagnosis.

At the center of Haset's illness experience is a clash between biomedical and lay illness 
narratives. The development of and advancements in hospital medicine has pressured sick individuals to rely on professional biomedical care. Sociologist Talcott Parsons's sick-role theory describes this relationship. Physicians become the spokespeople for patients' diseases, making ill people yield their narratives to disease and medical personnel (Parsons 1991 [1951]). Thus, ill people lose control of their narratives to the powers of medical institutions. When Haset's physician foregrounded her TSH count, Haset lost control of her life to hypothyroidism. Her doctor's medical interpretation overpowered her illness narrative, delegitimizing Haset's personal knowledge about her body with empirical data. While the general expectation is to entrust care to a doctor, the prolonged nature of chronic illnesses generates narratives that question and nullify authoritative discourses. Haset's physician reinforced an underlying concept of the sick-role theory that "physicians are responsible more to professional codes than to individual patients" (Frank 1995, 15). This standard adheres to values upheld by medical institutions, and its "greatest responsibility...is achieved when the professional places adherence to the profession before the particular demands of any individual patient" (Frank 1995, 15). This approach to medical care is accountable to "the factual truth of medical science, the beneficent truth of institutional management in the hospital, and ultimately...biopolitics" (Frank 1995, 15-16).

Haset's frustration, however, highlights lay people's agency in foregrounding their illness perceptions. Parsons's sick-role theory portrays patients as passive individuals who easily submit to physicians' biomedical explanations. This depiction overshadows sick people who resist doctors' restrictions by centering their own daily illness experiences and personal voices. Haset challenges her physicians' biomedical narrative by outwardly questioning the implications of her diagnosis and treatment. Haset eventually adheres to her doctor's medical advice, but this compliance demonstrates that biomedical discourses coexist with lay illness narratives. Both types of narratives occur within the same time and space as well as the same physical body despite their dissimilarities. Patients juggle these accounts to craft their own physiological, mental, and social treatments.

Haset's account conveys a chaotic narrative. Frank (1995) defines this genre as stories with plots in which life does not get better. Chaotic narratives have a theme of uncontrollability, which is captured through their incoherent storylines or absent happy endings. Haset's narrative partly reflects these elements in how she depicts the sudden emergence of her chronic illness. Haset has a high TSH count out of nowhere, and she is officially diagnosed with hypothyroidism. She does not have control over this disease's duration because she will live with it for the rest of her life. This diagnosis is an abrupt event, interfering with Haset's everyday life, whether it be through taking daily medication or dealing with its physical side effects. In her interview, Haset subtly conveyed her frustration at these bodily changes caused by her medication. They make her feel less of a woman because these side effects impact her physical appearance, and they are another type of interruption, which Haset must internalize. But does Haset perceive her illness as disorderly?

Even though these physical changes happened so quickly for her, Haset makes sense of them through conversations with her coworkers who also have hypothyroidism. These discussions allow her to express the emotions she had masked at the time of her diagnosis, helping Haset combine multiple frames of explanation: "[M]y coworkers-most of them, they have this issue.... I was saying here, 'Why am I having [hypothyroidism]?' I-I thought I eat, uh, a good nutrition. I can get everything. Why this come? [sic] This and that. And then, some of the nurses who has that, they explain to me: 'That [sic] a hormone change going on in your body."' Haset learned from her colleagues that dry hair and uncontrollable weight gain are common side effects of hypothyroidism medication. One coworker shared in detail with Haset her experience with the illness:

My coworker told me her hair is dry, like the- like a dandruff thing is coming. You can see it. It's beautiful, long hair. You can see when she wash [sic] and let it down. You can 
see [the dandruff] on her skin. The dryness is showing. That is the only side effect she had.... And then, gain weight. There is no way to control to lose it, to be like the skinny person. To be like skinny. "It's hard," she said. She couldn't get her old weight.... She told me that. Those two things was [sic] hit her bad because of the medicine she say.... So, those kind [sic] of things make me completely hate the medicine. If I get a chance, I mean, if it is another chance, I wish I can stop it and try something else.

Haset openly vents to her colleagues the disruptions brought by her chronic illness. This freedom challenges the Ethiopian cultural notion of pride and biomedical narratives that have been positioned as the dominant form of health narrative. Haset conveys her vulnerability to her coworkers, a majority of whom are from Southeast Asia. Not only is Haset expanding her social networks across interethnic groups through this discourse, but she and her colleagues are also confronting their native culture's stigmatizing notions of chronic illnesses (Uba 1992; Lim 2015; Muecke 1983). When they disclose their experiences with hypothyroidism, Haset and her coworkers find support and learn from each other's stories. These individuals reveal their frustrations with their treatments and how they grapple with different cultural explanations of their illnesses. In essence, Haset and her colleagues create their personal illness narratives from a hybrid of discourses, ranging in cultural knowledge and health expectations. Haset circumnavigates the cultural stigma attached to discussing chronic illnesses through this social interaction, and she counteracts allopathic explanations of her health condition. Haset's physician imposed a biomedical narrative, which restricted Haset from freely revealing her physical and emotional feelings. However, Haset's conversations with her coworkers affirm her illness experiences and perceptions. She inhabits multiple worlds as an immigrant, a woman, and a healthcare worker. Through this mix of discourses, Haset refines her identity in the midst of uncertainty. Her stories are "no longer...secondary.... They have their own primary importance" (Frank 1995, 7). These accounts make her life more orderly by realigning her body, self, and her "life's map" (Frank 1995, 7).

\section{Faith: "God will free me from this illness one day not medicine"}

When Almaz was diagnosed with type 2 diabetes, she was outraged. "How could it be me? I don't eat unhealthy foods?!" exclaimed Almaz before taking a sip from her teacup. Almaz and I were sitting at her dining table and eating breakfast-qinche (bulgur wheat with Ethiopian butter) with moringa tea. At the start of our conversation, Almaz exuded her animated personality. Admittedly, I had some trouble keeping up with Almaz's zeal and fastpaced Amharic. But when we began discussing her illness experience, Almaz's behavior changed. She became shy, fiddling with her teacup's handle and staring at the dining table. It was as if Almaz had morphed into a different person.

Almaz was born in Dessie, Wollo, in northeastern Ethiopia in 1962. Her family moved to Addis Ababa soon afterward, but at six-years old, Almaz was sent to live with Emamaya, a neighborhood mother-figure. As an energetic child, Almaz often got in trouble. Almaz laughingly reminisced, "I just remember getting disciplined a lot! I loved playing, but Emamaya likes peace and quiet." Almaz lived with Emamaya until she graduated from high school. Then, Almaz became an assistant secretary at a military base, which closed when the Tigrayan-led Ethiopian People's Revolutionary Democratic Front overthrew the Derg in 1991. But as an outspoken critic of both groups, Almaz had to escape to Sudan. "I had the chance to go elsewhere [i.e. Europe or the U.S.] from Sudan, but I didn't want to wait another six months or undertake a dangerous journey," explained Almaz. She returned to Ethiopia, where she continued to openly express her political views. Almaz soon became a political target. So with the support of her friends, she left for Cairo, Egypt, in March of 1995.

Almaz persevered despite these circumstances. In Cairo, she worked as a nanny for a wealthy family. Similar to Genet, Almaz fondly reminisced about her time in Egypt, raising two boys. "We would go on vacations 
together.... We relaxed and played [together].... It was a good time," recounted Almaz with a big smile. The children's parents had a friend who worked at the Egyptian Embassy in Washington, D.C. When they overheard Almaz express her desire to immigrate to the U.S., the parents helped her fulfill her desire with the embassy's support. Almaz arrived in D.C. in March 1998, where she reconnected with childhood friends and lived with them in a small apartment while working various service jobs. She got married in 2003 but decided to not have kids for personal reasons. Two years later, Almaz enrolled in CNA courses, and she was employed at a senior living facility, where she still works today. Almaz's work makes her aware of critical health issues, but she did not expect them to personally affect her.

Almaz was appalled when she was diagnosed with type 2 diabetes. Her biological mother had diabetes although Almaz does not know which type. Almaz felt targeted by her diagnosis, and she even refused to take her medication at first: "The doctor gave me fifteen days [to start taking medication on my own], and then she made me start taking it." Almaz did not think her unusually high water intake indicated that she had diabetes, but her abnormally high blood glucose levels confirmed that she had the disease. Almaz's denial was further reinforced by her husband's reaction. "He denied all diagnosis!" exclaimed Almaz with a nervous laugh. It has been almost ten years since Almaz's diagnosis. But to this day, she still does not accept her health status, and she has altered her lifestyle minimally in response to her illness. Almaz admitted, "I exercise a little bit, but really my mind hasn't fully accepted that I have diabetes." Why does Almaz react this way?

First, Almaz does not feel physical pain or symptoms from her illness. She claimed, "I don't feel anything. Sometimes, I eat white bread and cake.... People have to remind me that I have to monitor what I eat." In fact, Almaz's untroubled approach is reinforced by her refusal to take recommended prescriptions. Almaz is given medication for high cholesterol in addition to insulin, but she stopped taking the former because she did not deem it necessary. Almaz stands by her own actions, asserting that "medicine extends your life, but it does not end your illness." Thus, Almaz trusts that prayer is more effective in dealing with her chronic health conditions. Almaz's goal is not to live a functional life with diabetes but to enjoy one without it. She believes that sickness is a spiritual warfare: "The devil wants you to take medicine, which hurts another organ. And then, the medication makes you sick, so you have to take another prescription." Almaz must trust God to win this war.

Additionally, Almaz believes her illness is a temporary fight. As a devout Ethiopian Orthodox, she trusts that God will bless her with "good health" as a result of her faith: "I view good health as a blessing from God. Bad health and sickness are from the devil.... I believe that God will free me from this illness one day not medicine." For Almaz, "good health" is ultimately being healed from type 2 diabetes, but until then, small health improvements are signs that God is working in her favor. Almaz admitted that there have been times when she did not take proper care of her diet, but God blessed her with good health results-an indication that Almaz was not meant to get diabetes. Almaz shared that she is so strongly rooted in this belief that "I don't take the [diabetes] medicine regularly.... Sometimes, I skip for three or four days. I forget other times, or during [Orthodox] fasts, I don't take it at all. It's God who has helped me so far." By focusing on Almaz's committed faith in God, I am not suggesting that Almaz is irresponsible toward her health. I observed her taking her medication on several occasions along with tsebel (holy water). Until she is healed, Almaz prioritizes giving gratitude to God to ensure the arrival of this victorious day. Faith is believing things that cannot be seen, and it empowers Almaz over biomedical illness narratives.

Similar to Haset, Almaz views her diagnosis as an unanticipated event. She was taking care of her physical health by eating nutritious foods and of her spiritual well-being through continuous fasting and prayer. However, Almaz was unexpectedly diagnosed with type 2 diabetes and high cholesterol. This lack of a clear origin in Almaz's illness story contributes to a sense of a disorderly future. To create stability, Almaz believes she should not rely on biomedical interventions. Rather, God will heal 
her of her health issues in response to her devotion to Him. Almaz's reaction to her diagnosis also echoes the tensions between biomedical and lay narratives. Almaz's resistance toward taking her prescriptions demonstrates her refusal to accept the medical interpretation of her body and health. She does not believe the numbers that showed she has high blood glucose levels. Instead, she trusts her physical senses. This defiance illustrates Almaz's struggle to stress the primacy of her perspective. While crafting and sharing her story, Almaz takes command over this unexpected change in her life. Her narrative is a meta-control over the challenges she has endured (Frank 1995). In this process of narration, Almaz is making sense of her experiences, arranging them in a way that is true to herself. Storytelling allows Almaz to generate order and to exert power in her life.

Unlike Haset, Almaz expresses optimism for her future health. Almaz's trust in God motivates her to believe that one day she will no longer live with type 2 diabetes. But until she is healed, Almaz must continue to demonstrate her faithfulness to God to overcome this illness. As a devout Orthodox Christian, Almaz follows the characteristics of individuals blessed by God in the Bible because of their commitment to Him. Such attributes are as simple as Almaz giving praise to God. During her interview, Almaz would interrupt our conversation when she discussed God's grace in her life, pointing her palms to the ceiling with her arms bent and saying Amharic blessings to God. This act of devotion is a way for Almaz to attain control in the midst of this life event. Although Almaz cannot immediately end the suffering brought by diabetes, she immerses herself in her spiritual beliefs. The end result may not come quickly, but this hope is what pushes Almaz to continue enduring the interruptions caused by her chronic illness. It is a relief, which stimulates determination and not defeat. This determination and optimism points to how illness does not deter her. Almaz's diagnosis reinforces her faith in God, motivating her to develop a stronger relationship with Him. Ultimately, Almaz emphasizes the significance of faith and hope, two beliefs that can help sick people endure the physiological, emotional, and psychological challenges of illness.

\section{Conclusion: "A good conversation is better than a good bed"}

"A good conversation is better than a good

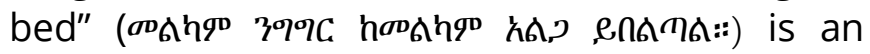
Amharic proverb that expresses how a pleasant discussion provides better comfort than adequate physical rest. Throughout my fieldwork, I noticed this sense of ease among my interlocutors as they shared their migration and illness narratives. I was in fact a bit surprised to observe my interviewees' openness in telling their stories, but this experience showed me the liberating and constraining elements of storytelling and how they can provide clarity on complicated issues yet not resolve problems from the past.

The goal of this article is to convey these complex features of narratives and to show how chronically ill Ethiopian immigrant women are active agents in shaping their stories. Genet, Haset, and Almaz find their own ways to assert control over their bodies and lives despite facing the pressures of the Ethiopian cultural notion of pride. For Genet, this declaration means confronting the cultural stigma of diabetes and personally disclosing her health status to her family. In response to her frustrating diagnosis, Haset turns to her coworkers, who help her deal with hypothyroidism by openly sharing their interpretations and experiences with this disease. Almaz casts her fears aside and places her faith in God, believing that He will heal her of diabetes. Each of these accounts make visible the multiple worlds that chronically ill Ethiopian immigrant women inhabit and that foster new meanings on their illness experiences.

I engage with illness narratives through a prism of personal, cultural, and religious ideas throughout this article because this approach conveys an intimate glimpse into my interlocutors' everyday lived realities. These perspectives humanize my interviewees' stories by recognizing these individuals' manifold experiences, multiple identities, and continually developing selves. As German literature scholar Jack Zipes (2012, 126) writes, "[s]tories are effective and we cannot do without them because they shape the way we live.... [W]e have an ethical responsibility to seek out those 
stories that benefit societies and provide a means for understanding the truths in our lives." The narratives I have collected represent a few of the plethora of stories that highlight the often-overlooked daily realities of immigrant women around the world. As a budding anthropologist and a daughter of immigrants, I aspire to continue capturing these narratives to better understand the complex challenges that immigrant women experience as they rebuild their lives and assert control over their bodies in unfamiliar countries. 


\section{Acknowledgements}

To my advisor Professor Lisa Koryushkina, thank you for supporting me on this long and challenging journey both during and after my undergraduate studies. To my interlocutors, I am humbled by your compassion, zeal, and generosity. You have all inspired me to pay it forward to future generations of Ethiopians. Lastly, I thank my mother and father, whose stories about growing up in and leaving Ethiopia gave birth to this project. Your experiences give me purpose, and they have shaped me into the woman I am today. 


\section{References}

Beaman, Jean. 2017. Citizen Outsider: Children of North African Immigrants in France. Berkeley: University of California Press.

Bekele, Meti. 2018. "How Social Norms Relate to Gender Inequality in Ethiopia." Population Reference Bureau. Accessed April 15, 2020. https://www.prb.org/insight/how-social-norms-relate-to-genderinequality-in-ethiopia/.

Berkman, Lisa F., and S. Leonard Syme. 1979. "Social Networks, Host Resistance, and Mortality: A Nine-Year Follow-Up Study of Alameda County Residents." American Journal of Epidemiology 109 (2): 186-204.

Bourdieu, Pierre. 1984. Distinction: A Social Critique of the Judgment of Taste. Cambridge: Harvard University Press.

Brettell, Caroline. 2008. “Theorizing Migration in Anthropology: The Social Construction of Networks Identities, Communities, and Global Scapes." In Migration Theory: Talking Across Disciplines, edited by C. Brettell and J. Hollifield, 113-159. London: Routledge Press.

Bury, Michael. 2001. "Illness Narratives: Fact or Fiction?" Sociology of Health and IIIness 23 (3): 263-285.

Capps, Randy, Kristen McCabe, and Michael Fix. 2012. “Diverse Streams: African Migration to the United States." Migration Policy Institute. Accessed February 6, 2018. https://

www.migrationpolicy.org/pubs/CBI-AfricanMigration.pdf.

Cohen, Sheldon, Benjamin H. Gottlieb, and Lynn G. Underwood. 2000. "Social Relationships and Health." In Social Support Measurement and Intervention: A Guide for Health and Social Scientists, edited by Sheldon Cohen, Benjamin H. Gottlieb, and Lynn G. Underwood, 3-25. Oxford: Oxford University Press.

Farmer, Paul. 2006. AIDS and Accusation: Haiti and the Geography of Blame. Berkeley: University of California Press.

Frank, Arthur W. 1995. The Wounded Storyteller: Body, Illness, and Ethics. Chicago: The University of Chicago Press.

Frank, Arthur W. 2010. Letting Stories Breathe: A Socio-Narratology. Chicago: The University of Chicago Press. 
Goldsmith, Daena J. 2004. Communicating Social

Support. Cambridge: Cambridge University Press.

Hatch, Elvin. 1989. "Theories of Social Honor." American Anthropologist91 (2): 341-353.

Kleinman, Arthur. 1988. The IIIness Narratives: Suffering, Healing, and The Human Condition. New York: Basic Books.

Lim, Sue. 2015. "Asian Cultural Values \& Health Beliefs \& the Impact They Have on Decisions around Nutrition and Physical Activity: A Locale Example of a Culturally Appropriate Approach." ANA Asian Forum. Accessed April 20, 2020. https://ana.org.nz/wp-content/ uploads/2016/10/Asian-Cultural-Beliefs-and-the-Impact-theyhave-on-Decisions-around-Nutrition-and-Physical-Activity.pdf.

Lloyd, Genevieve. 1993. Being in Time: Selves and Narrators in Philosophy and Literature. London: Routledge Press.

Malara, Diego Maria, and Tom Boylston. 2016. “Vertical Love: Forms of Submission and Top- Down Power in Orthodox Ethiopia." Social Analysis: The International Journal of Anthropology 60 (4): 40-57.

Massey, Douglas S. 1990. "Social Structure, Household Strategies, and the Cumulative Causation of Migration." Population Index 56: 3-26.

Migration Policy Institute. 2014. "The Ethiopian Diaspora in the United States." RAD Diaspora Profile. Accessed February 6, 2018. https://www.migrationpolicy.org/sites/default/files/publications/ RAD-Ethiopia.pdf.

Muecke, M. A. 1983. "Caring for Southeast Asian Refugee Patients in the USA." American Journal of Public Health 73 (4): 431-438.

Parsons, Talcott. 1991 [1951]. The Social Systems. London: Routledge Press.

Revenson, Tracey A., Kathleen M. Schiaffino, S. Deborah Majerovitz, and Allan Gibofsky. 1991. "Social support as a double-edged sword: the relation of positive and problematic support to depression among rheumatoid arthritis patients." Social Science \& Medicine 33 (7): 807-813. 
Sellasie, Sergew Hable, and Belaynesh Mikael. 2003. "The Church of Ethiopia: A Panorama of History and Spiritual Life." EOTC, 1970. https://www.ethiopianorthodox.org/english/ethiopian worship.html.

Smith, Kirsten P., and Nicholas A. Christakis. 2008. "Social Networks and Health." Annual Review of Sociology 34: 405-429.

Uba, Laura. 1992. "Cultural Barriers to Health Care for Southeast Asian Refugees." Public Health Reports 107 (5): 544-548.

US Census. 2019a. "Place of Birth for the Foreign-Born Population in the United States." American Community Survey. Accessed October 28, 2020. https://data.census.gov/cedsci/table? $q=$ eritreans\&tid=ACSDT1Y2019.B05006\&hidePreview=false.

US Census. 2019b. "Place of Birth for the Foreign-Born Population in the United States - California." American Community Survey. Accessed October 28, 2020. https://data.census.gov/cedsci/table? $\mathrm{q}=$ eritreans\%20in $\%$ 20california\&tid=ACSDT1Y2019.B05006\&hidePreview=true.

Wilson, Jill H., and Shelly Habecker. 2008. "The Lure of the Capital City: An Anthro- geographical Analysis of Recent African Immigration to Washington, D.C." Population, Space and Place 14: 443-448.

Wright, Kevin. 2016. “Social Networks, Interpersonal Social Support, and Health Outcomes: A Health Communication Perspective." Frontiers in Communication 1 (10): 1-10.

Zipes, Jack. 2012. "Living through Stories." Storytelling, Self, Society 8 (2): 126-129. 